\title{
Characteristics of PCDD/Fs in Flue Gas from MSWIs and HWIs: Emission Levels, Profiles and Environmental Influence
}

\author{
Juan Qiü, Minghui Tang", Yaqi Peng, Shengyong Lu*, Xiaodong Li, Jianhua Yan \\ State Key Laboratory for Clean Energy Utilization, Institute for Thermal Power Engineering, Zhejiang University, \\ Hangzhou 310027, China
}

\begin{abstract}
Polychlorinated dibenzo-p-dioxins and dibenzofurans (PCDD/Fs) in the flue gas from two types of waste incinerators (municipal solid waste incinerators and hazardous waste incinerators) the most commonly used in China were investigated in this study. The PCDD/F emissions from the stack gas of the waste incinerators showed a large variation from 0.016 to

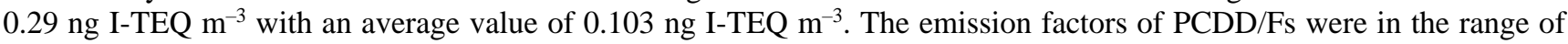
0.056-0.607 $\mu \mathrm{g}$ I-TEQ $\mathrm{t}^{-1}$ (average $0.235 \mu \mathrm{g}$ I-TEQ $\mathrm{t}^{-1}$ ) for municipal solid waste incinerators (MSWIs) and 0.07-3.27

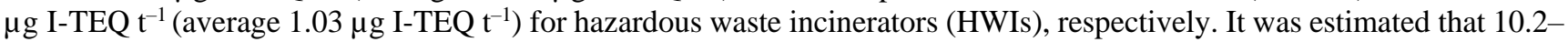
$88.0 \mathrm{mg}$ I-TEQ (average $35.0 \mathrm{mg}$ I-TEQ) and 1.13-53.0 mg I-TEQ (average $17.1 \mathrm{mg}$ I-TEQ) of PCDD/Fs were annually released to the atmosphere, respectively from MSWIs and HWIs. The level and congener patterns of 17 species of PCDD/Fs in the ambient air and in soil samples around the MSWIs and HWIs were investigated to evaluate the influence of PCDD/F emission on the environment. The PCDD/F concentrations in the ambient air from the 5 MSWIs and 4 HWIs ranged from 0.088 to $13.9 \mathrm{pg}$ I-TEQ $\mathrm{m}^{-3}$ with an average value of $0.185 \mathrm{pg} \mathrm{I-TEQ}^{-3}$. The soil samples in the vicinity of MSWIs and HWIs presented concentrations between 0.68 and $16.0 \mathrm{ng}$ I-TEQ $\mathrm{kg}^{-1}$ with an average value of $3.98 \mathrm{ng}$ I-TEQ kg- . This study showed that PCDD/F emission from the incineration plants had an obvious impact on the surrounding ambient air.
\end{abstract}

Keywords: PCDD/Fs; Flue gas; Emission factor; Air; Soil.

\section{INTRODUCTION}

Municipal solid waste (MSW) incineration in China has been boosted more than twelve fold in the past decade, in response to the rapid increase of MSW (Lu et al., 2017; Zhu et al., 2018). In addition, the amount of hazardous waste (HW) in China is increasing greatly from 10.79 million tons in 2007 to 69.37 million tons in 2017 as the development of economy (National Bureau of Statistics of China, 2008, 2018). Hazardous waste, including industrial hazardous waste, medical waste, and household hazardous waste (Duan et al., 2008), presents some particular characteristics of ignitability, corrosivity, reactivity, and toxicity. Trinh and Chang (2018) reported that municipal solid waste incinerators (MSWIs) were important emission sources of polychlorinated dibenzo$p$-dioxins and dibenzofurans (PCDD/Fs, also referred to as dioxin) to ambient air (Ni et al., 2009; Hu et al., 2014; Wang

\footnotetext{
${ }^{\#}$ These authors contributed equally.

* Corresponding author.

Tel.: +8613957137049; Fax: +8657187952438

E-mail address: lushy@zju.edu.cn
}

et al., 2015; Bai et al., 2017; Ngo et al., 2018; Trinh and Chang, 2018). Dopico and Gomez (2015) and Zhan et al. (2019) also reported that the emission factor of PCDD/Fs from hazardous waste incinerators (HWIs) is significantly higher than those from MSWIs. Therefore, it is important to control the PCDD/F emissions from HWIs.

The emission of PCDD/Fs has recently been investigated extensively in the waste incineration process (Bie et al., 2007; Choi et al., 2008; Gao et al., 2009; Ni et al., 2009; Zhu et al., 2018). Choi et al. (2008) investigated dioxins in gases emitted from MSWIs and HWIs, finding the concentration of PCDD/Fs ranged from 0.05 to $609.27 \mathrm{ng}^{\mathrm{TEQ}} \mathrm{Nm}^{-3}$. Bie et al. (2007) discovered the average dioxin emission in the flue gases from MSWIs by applying a twin internal fluidized bed incinerator in Harbin was $0.02 \mathrm{ng} \mathrm{I-TEQ} \mathrm{Nm}{ }^{-3}$. Ni et al. (2009) analyzed the congener profiles from various MSWIs, estimating the emission factors of PCDD/Fs in the stack gas to be $0.169-10.7 \mu \mathrm{g}$ TEQ $\mathrm{t}^{-1} \mathrm{MSW}$ with an average value of $1.73 \mu \mathrm{g}$ TEQ $\mathrm{t}^{-1} \mathrm{MSW}$. Gao et al. (2009) revealed the stack gas emissions of PCDD/Fs from hospital waste incinerators (HWIs) exhibited a large variation (0.08-31.6 ng I-TEQ $\left.\mathrm{Nm}^{-3}\right)$. Zhu et al. (2018) revealed that the concentrations of PCDD/F emissions in stack gas from 6 MSWIs were in the range of $0.007-0.059 \mathrm{ng}$ TEQ $\mathrm{Nm}^{-3}$. The emission factors of PCDD/Fs from 6 MSWIs varied from 0.027 to $0.225 \mathrm{mg} \mathrm{I-TEQ} \mathrm{t}^{-1}$, 
with a mean value of $0.17 \mathrm{mg}$ I-TEQ $\mathrm{t}^{-1}$ waste.

The PCDD/F concentrations and congeners distribution in the surrounding environment of different incinerators were investigated and studied in the past years (Oh et al., 2006; Yan et al., 2008; Li et al., 2018; Zhou et al., 2019). Oh et al. (2006) studied the influence of MSWI on the PCDD/Fs levels in ambient air and soil, and the concentration of PCDD/Fs in air samples and soil samples ranged from 0.22 to $1.16 \mathrm{ng}$ I-TEQ $\mathrm{Nm}^{-3}$ and 1.25 to $75.0 \mathrm{ng}$ I-TEQ $\mathrm{kg}^{-1}$, respectively. Zhou et al. (2019) studied the characteristics of PCDD/Fs in surface soil around an iron and steel plant and the PCDD/Fs content in the soil ranged from 0.16 to 4.5 ng I-TEQ $\mathrm{kg}^{-1}$. However, few studies focused on the emission characteristics of PCDD/Fs and PCDD/Fs levels in the ambient air and soil samples from HWIs, and the similarities and differences between MSWIs and HWIs were still obscure in terms of PCDD/Fs.

In order to investigate the emission characteristics of PCDD/Fs the in stack gas and PCDD/Fs levels in the ambient air, soil samples from MSWIs and HWIs in China, stack gas samples from 5 MSWIs and 4 HWIs and ambient air and soil samples around the plants were collected and analyzed. The objectives of this study were: (1) to compare the PCDD/F concentration of stack gas and congener profiles of PCDD/Fs from 5 MSWIs and 4 HWIs; (2) to investigate the emission factors of PCDD/Fs and the annual emission of PCDD/Fs; (3) to analyze the possible grouping of similar emissions and demonstrate the PCDD/F congeners profiles using principal component analysis (PCA); (4) to study the $\mathrm{PCDD} / \mathrm{F}$ concentration and patterns in the ambient air and soil samples from MSWIs and HWIs.

\section{MATERIALS AND METHODS}

\section{Sample Collection}

Stack gas samples were collected from municipal solid waste incinerators (MW01-MW05) and hazardous waste incinerators (HW01-HW04) in China, and the basic information for these incinerators and their APCDs were given in Table 1. The MW01-MW05 treated municipal solid waste incinerators. The HW01 treated dye waste, coke, organic sludge, waste oil, paint waste water with rotary kiln. The HW02 dealt with waste gas and liquid produced during VCM production. The HW03 treated wastes composed of oily refuse, rock debris, mud, etc. The HW04 treated medical waste.

Flue gas sampling was conducted using isokinetic samplers (Model KNJ23, KNJ corporation, Korea), complying with U.S. EPA Method 23a; and the specific sampling method was described in detail in previous study (Chen et al., 2008). All sampling points were located downstream to APCDs. Ambient air sampling was performed in winter and summer at the boundary of the plants over 2 meters in height, and down the wind. Ambient air samples were collected according to U.S. EPA Method TO-9A (U.S. EPA, 1999), as described in detail by Chen et al. (2015). The sampling time and air volumes were about $24 \mathrm{~h}$ and $900-1100 \mathrm{~m}^{3}$, respectively (Table 2). The soil samples (approximately $2 \mathrm{~kg}$ per sample) were taken from the upper $200 \mathrm{~mm}$ (MW01-MW05, HW02, HW04) and 200-400 mm (HW01, HW03) at the same sites.

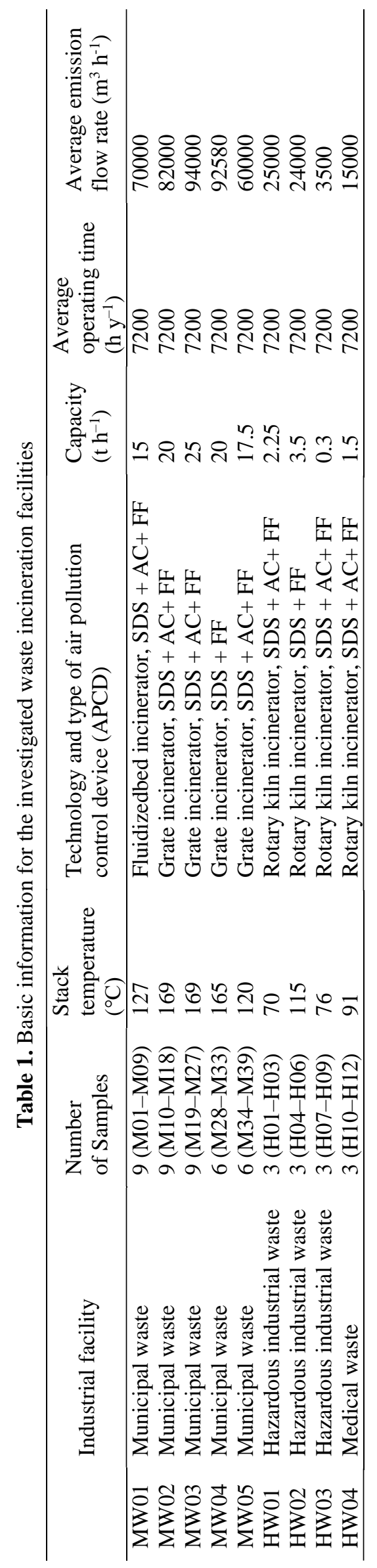


Table 2. Information for the ambient air samples.

\begin{tabular}{llllll}
\hline Sample & $\begin{array}{l}\text { Sampling } \\
\text { season }\end{array}$ & Sampling position & $\begin{array}{l}\text { Sampling } \\
\text { volume }\left(\mathrm{m}^{3}\right)\end{array}$ & $\begin{array}{l}\text { Wind and mean } \\
\text { temperature }\left({ }^{\circ} \mathrm{C}\right)\end{array}$ & $\begin{array}{l}\text { PCDD/Fs } \\
\left(\mathrm{pg} \mathrm{I}-\mathrm{TEQ} \mathrm{m}^{-3}\right)\end{array}$ \\
\hline MW01-A1 & Winter & Out of west gate & 1007.8 & Southwest, 9.3 & $0.433(0.26,0.75,0.29)$ \\
MW01-A2 & Summer & Out of west gate & 1007.9 & Southeast, 28.8 & $0.102(0.088,0.077,0.14)$ \\
MW01-A3 & Summer & By the chimney & 1007.9 & Southeast, 29.0 & $13.9(3.89,11.1,26.7)$ \\
MW02-A1 & Winter & Out of corner gate & 911.1 & Southwest, 10.5 & $0.207(0.38,0.14,0.10)$ \\
MW02-A2 & Winter & Out of west gate & 908.3 & Southwest, 9.2 & $0.421(0.75,0.43,0.082)$ \\
MW03-A1 & Winter & Out of east gate & 1007.8 & Southwest, 10.0 & $0.088(0.11,0.11,0.043)$ \\
MW04-A1 & Winter & Out of main gate & 959.8 & West, 5.6 & $0.114(0.16,0.10,0.082)$ \\
MW05-A1 & Winter & Out of main gate & 984.3 & Northwest, 5.0 & $0.34(0.39,0.41,0.22)$ \\
HW01-A1 & Winter & Out of main gate & 1007.8 & Southwest, 11.9 & $0.103(0.11,0.11,0.090)$ \\
HW02-A1 & Winter & Out of east gate & 996.2 & Southwest, 8.7 & $0.11(0.12,0.14,0.070)$ \\
HW03-A1 & Winter & Out of main gate & 1007.8 & Northwest,-2.4 & $0.229(0.59,0.071,0.025)$ \\
HW03-A2 & Summer & By the chimney & 1007.9 & South, 26.6 & $0.427(0.25,0.27,0.76)$ \\
HW03-A3 & Summer & Out of main gate & 1007.9 & East, 26.6 & $0.076(0.13,0.048,0.049)$ \\
HW04-A1 & Winter & By the maintenance shop & 984.2 & North, -2.0 & $0.175(0.047,0.069,0.41)$ \\
\hline
\end{tabular}

\section{Sample Extraction and Analysis}

The PCDD/Fs analysis of stack gas and ambient air samples were performed according to the U.S. EPA Method 23 (U.S. EPA, 1995). Detailed steps of analysis method of the PCDD/Fs could be found from our previous studies (Chen et al., 2014; Chen et al., 2016). The soil samples were dried until constant weight and then they were ground and screened by a $2-\mathrm{mm}$ sieve. About $500 \mathrm{~g}$ of each soil sample was finally homogenized through a 60-mesh sieve, and was refrigerated until analysis. And the detailed steps of pretreatment and analysis could be found from our previous study (Yan et al., 2008).

\section{Statistical Analysis}

To better understand the congener profiles of dioxins in stack gases from various MSWIs and HWIs, principal component analysis (PCA) were used to evaluate the possible groupings of similar emissions and the dominant congeners in a defined grouping. Prior to analysis, the PCDD/F congeners levels were normalized with respect to the total PCDD/F concentration in the relevant sample. The statistical analyses were performed using the SPSS 20.0 software.

\section{RESULTS AND DISCUSSION}

\section{TEQ Contribution of PCDD/Fs in Stack Gas}

The gas emission levels of PCDD/Fs and the PCDF/PCDD weight ratio from 9 waste incineration facilities in China were investigated, and the results were presented in Fig. 1. The emissions of PCDD/Fs ranged from 0.016 to $0.29 \mathrm{ng} \mathrm{I-TEQ} \mathrm{m}^{-3}$

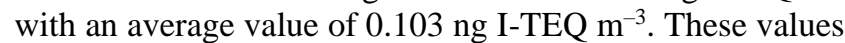
except HW02 and HW03 were all below the emission limit of national standard in China $\left(0.1 \mathrm{ng}\right.$ I-TEQ $\left.\mathrm{m}^{-3}\right)$ (China MEP, 2014). However, the PCDD/F emissions from HW02 and HW03 were 0.29 and 0.25 ng I-TEQ $\mathrm{m}^{-3}$ respectively, indicating more improvement space for PCDD/Fs control technologies in hazardous waste incinerators. The proportion of PCDF much higher than that of PCDD as in Fig. 1 indicating that PCDF was the main contributor to TEQ value in flue gas. Pham et al. (2019a) reported that concentrations of PCDD/Fs in flue gas were in the range of $13.4-17.6 \mathrm{pg}$ TEQ $\mathrm{m}^{-3}$ (mean: $15.5 \mathrm{pg}$ TEQ $\mathrm{m}^{-3}$ ) for MSWIs and 12.7-438 pg TEQ $\mathrm{m}^{-3}$ (mean: $125 \mathrm{pg}$ TEQ $\mathrm{m}^{-3}$ ) for medical waste incinerators (MWIs), respectively. Zhu et al. (2018) reported that concentrations of PCDD/Fs in stack gas from MSWIs were in the range of $0.007-0.059 \mathrm{ng}^{\mathrm{T}} \mathrm{TEQ} \mathrm{\textrm {m } ^ { - 3 }}$.

As in Fig. 2, the 50\% for HWIs was much higher than that for MSWIs, indicating that HWIs were generally characterized by higher emission levels than MSWIs in China.Three potential factors were identified to affect the concentration and the congener distributions of PCDD/Fs in incinerators: the types of furnace, the composition of APCDs, and waste composition (chlorine content in the waste) (Wang et al., 2003; Gao et al., 2009). Wastes incinerated at a low temperature yield a higher TEQ value than a high temperature. Besides, the absence or removal of chlorine in wastes effectively decreased the emission TEQ values (Wikstrom et al., 1996; Nzihou et $a l .$, 2012). Many studies focused on the relationship between chlorine and PCDD/Fs, and the effect of chlorine content in the feeding waste on PCDD/Fs formation was obviously. Wang et al. (2003) and Li et al. (2017) reported that MSW contains $0.2-0.8 \%$ chlorine, while the content of chlorine in hazardous waste is generally higher than municipal solid waste, which accelerates the formation of PCDD/F. The samples that did not contain chlorine or were not combusted with chlorides exhibited low emission TEQ values (Wikstrom et al., 1996; Nzihou et al., 2012).

\section{Estimated Emission Factor and Emission of PCDD/Fs from MSWIs and HWIs}

Much work so far focused on the gas emission of PCDD/Fs from MSWIs and HWIs in China by using the emission factor (EF) to calculate the annual emission (EA) of PCDD/Fs (Li et al., 2017; Zhu et al., 2018; Pham et al., 2019a, b).

\section{EF $\left(\mu \mathrm{g} \mathrm{I-TEQ} \mathrm{t}^{-1}\right)=$}

[concentration in flue gas $\left(\mathrm{ng}\right.$ I-TEQ $\left.\mathrm{m}^{-3}\right) \times$ flue gas flow rate $\left.\left(\mathrm{m}^{3} \cdot \mathrm{h}^{-1}\right)\right] /\left[\right.$ capacity level $\left(\mathrm{t} \mathrm{h}^{-1}\right) \times 10^{3}$ ] 


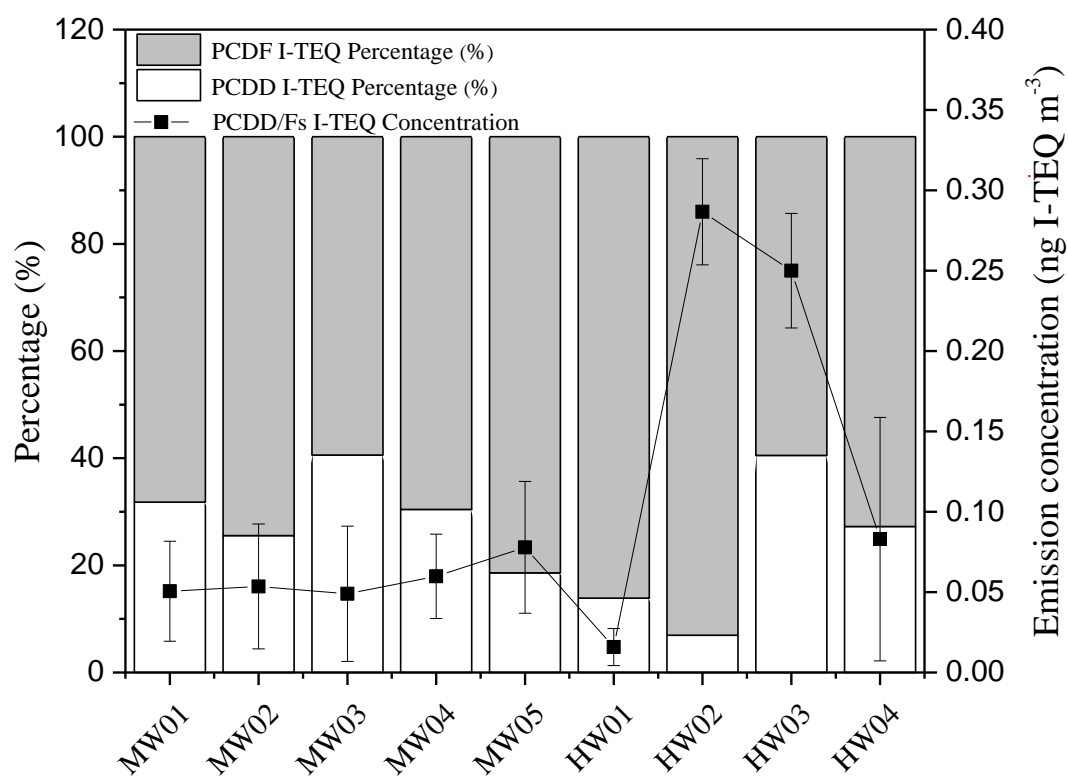

Fig. 1. Emission levels of PCDD/Fs from the 9 waste incinerators.

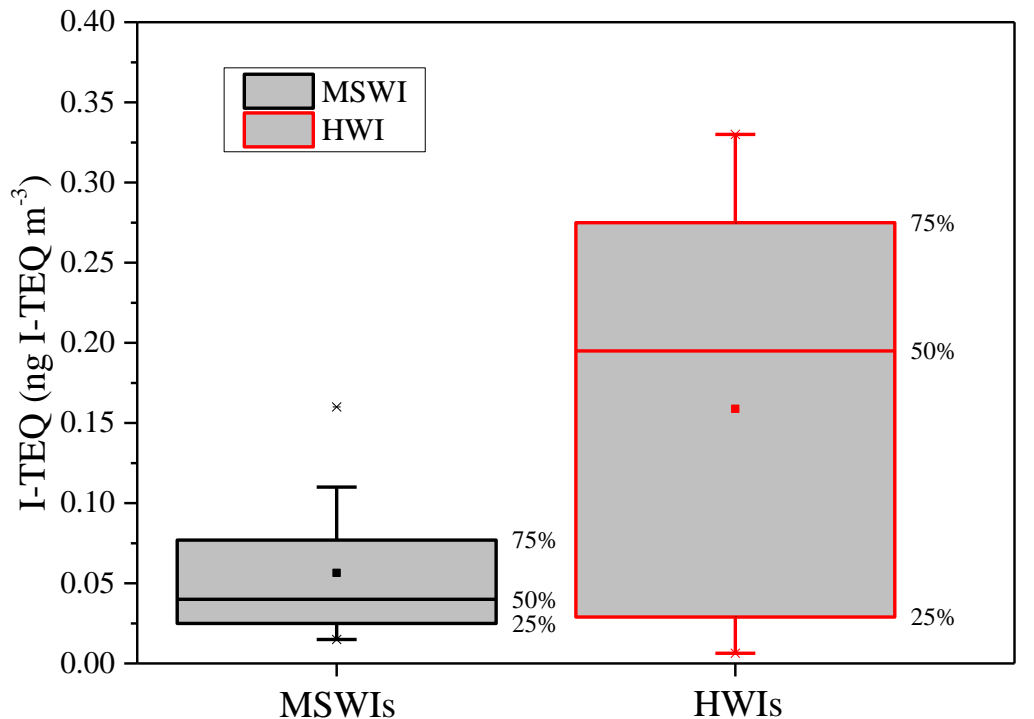

Fig. 2. PCDD/Fs statistical parameters for stack gas samples from MSWIs and HWIs: mean (•), 25\%, 50\% and 75\%.

EA $\left(m g\right.$ I-TEQ $\left.y^{-1}\right)=$

[emission factor $\left(\mu \mathrm{g}\right.$ I-TEQ $\left.\mathrm{t}^{-1}\right) \times$ capacity level $\left(\mathrm{t} \mathrm{h}^{-1}\right) \times$ average operating $\left.\left(\mathrm{h} \mathrm{y}^{-1}\right)\right] / 10^{3}$

Estimated emission factors and annual emission amounts of PCDD/Fs (mean concentrations and the ranges) from flue gas of the 5 MSWIs, 4 HWIs and the cases from literatures were presented in Table 3 .

In this study, the emission factors of PCDD/Fs to the atmosphere from 5 MSWIs varied from 0.056 to 0.607 $\mu \mathrm{g}$ I-TEQ $\mathrm{t}^{-1}$ MSW (mean: $0.235 \mu \mathrm{g}$ I-TEQ $\mathrm{t}^{-1}$ ). It was estimated that $10.2-88.0 \mathrm{mg}$ I-TEQ of PCDD/Fs (mean: $35.0 \mathrm{mg}$ I-TEQ of PCDD/Fs) were annually released to the atmosphere from MSWIs. In particular, the mean EF values and EA values of the MSW were similar, respectively. These values were in good consistent with the study of Zhu et al.
(2018), in which the EF and EA values ranged in 0.027$0.225 \mu \mathrm{g} \mathrm{I}^{-T E Q ~} \mathrm{t}^{-1}$ (mean value of $0.17 \mu \mathrm{g} \mathrm{I}$-TEQ t $^{-1}$ ) and in 5.36-101 mg I-TEQ (mean: $35.0 \mathrm{mg}$ I-TEQ), respectively.

The EF values ranged from 0.07 to $3.27 \mu \mathrm{g} \mathrm{I-TEQ} \mathrm{t}^{-1}$ for

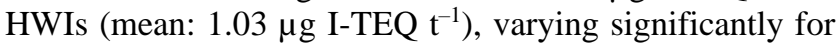
different HWIs. PCDD/Fs annual released to the atmosphere were estimated as 1.13-53.0 mg I-TEQ (mean: $17.1 \mathrm{mg}$ I-TEQ) in HWI. The noticeable EF value of HW03 among HWIs could be attributed to the particularly treated wastes, which were composed of oily refuse, rock debris, mud, etc.

Until 2018, 352 MSWIs which had a yearly capacity of 89.4 million tons were running in China, then the estimated annual emission amounts of PCDD/Fs from flue gas was $22.3 \mathrm{~g}$ TEQ. And the scale of HWI treatment reached 6.06 million tons per year, the estimated annual emission amounts of PCDD/Fs from flue gas was $6.51 \mathrm{~g}$ TEQ. 
Table 3. Mean emission factor and emission of PCDD/Fs from 5 MSWIs, 4 HWIs and cases from the literatures.

\begin{tabular}{|c|c|c|c|c|}
\hline \multicolumn{2}{|c|}{ Classification } & $\begin{array}{l}\text { Emission factor } \\
\left(\mu \mathrm{g} \mathrm{I-TEQ} t^{-1}\right)\end{array}$ & $\begin{array}{l}\text { Annual emission amount } \\
\left(\mathrm{mg} \mathrm{I}-\mathrm{TEQ} \cdot \mathrm{y}^{-1}\right)\end{array}$ & References \\
\hline \multicolumn{2}{|l|}{ MW01 } & $0.238(0.121-0.607)$ & $25.7(13.1-65.5)$ & This study \\
\hline \multicolumn{2}{|l|}{ MW02 } & $0.221(0.090-0.533)$ & $31.9(13.0-76.8)$ & This study \\
\hline \multicolumn{2}{|l|}{ MW03 } & $0.244(0.056-0.489)$ & $44.0(10.2-88.0)$ & This study \\
\hline \multicolumn{2}{|l|}{ MW04 } & $0.278(0.171-0.509)$ & $40.0(24.7-73.3)$ & This study \\
\hline \multicolumn{2}{|l|}{ MW05 } & $0.266(0.106-0.549)$ & $33.5(13.4-69.1)$ & This study \\
\hline \multicolumn{2}{|l|}{ HW01 } & $0.176(0.07-0.356)$ & $2.85(1.13-5.76)$ & This study \\
\hline \multicolumn{2}{|l|}{ HW02 } & $0.199(1.72-2.26)$ & $50.1(43.2-53.0)$ & This study \\
\hline \multicolumn{2}{|l|}{ HW03 } & $2.92(2.33-3.27)$ & $6.30(5.04-7.06)$ & This study \\
\hline \multicolumn{2}{|l|}{ HW04 } & $0.83(0.26-1.9)$ & $8.96(2.81-20.5)$ & This study \\
\hline \multirow[t]{3}{*}{ China } & Municipal waste & $0.17(0.027-0.225)$ & $35.0(5.36-101)$ & Zhu et al., 2018 \\
\hline & Hospital Waste & $63.3(0.78-474)$ & 4.87 & Gao et al., 2009 \\
\hline & Medical waste & $1.92(0.033-4.9)$ & $3.15(0.217-18.8)$ & Li et al., 2017 \\
\hline \multirow[t]{3}{*}{ VietNam } & Municipal waste & $0.111(0.096-0.127)$ & $0.3(0.2-0.4)$ & Pham et al., 2019a \\
\hline & Industrial waste & $0.991(0.663-1.43)$ & $6.4(4.3-9.2)$ & \\
\hline & Medical waste & $16.4(1.68-57.5)$ & $23.6(2.4-82.7)$ & \\
\hline
\end{tabular}

\section{Congener Profiles of PCDD/Fs in Stack Gas}

Fig. 3 shows the scope plot of principal component analysis, for relative contributions of the 17 toxic dioxin congeners. The first principal component (PC1) took into account $48.0 \%$ of the variability of the data set, and the second principal component (PC2) accounted for $43.7 \%$ of the total variance. PC1 and PC2 accounted for $91.7 \%$ of the total variance. The score plot of PCA indicated that all investigated MSWIs and HWIs could be assigned to three groups. Group1 on the left were samples from HW01 and HW02, group 2 in the middle were samples from MSWIs and HW04, and group 3 on the right included samples from HW03. As in Fig. 3, the distribution of PCDD/F congeners was similar between the samples from MSWIs, but different between the samples from MSWIs and HWIs. Moreover, samples from HWIs were also distinct.

Fig. 4 presented the congener profiles of $\mathrm{PCDD} / \mathrm{Fs}$ in each group. Congener profiles of $17 \mathrm{PCDD} / \mathrm{F}$ congeners in the samples were analyzed to understand the formation pathways and release behavior of dioxins in the investigated facilities. The mass ratios of PCDFs to PCDDs ( $\mathrm{R}_{\mathrm{F} / \mathrm{D}}$ ) was always used to estimate the formation of dioxins by the de novo synthesis $\left(\mathrm{R}_{\mathrm{F} / \mathrm{D}}>1\right)$ or by precursor formation $\left(\mathrm{R}_{\mathrm{F} / \mathrm{D}}<1\right)$ (Luijk et al., 1994; Huang and Buekens, 1995; Tuppurainen et al., 2000; Everaert and Baeyens, 2002; Pham et al., 2019b). The congener distributions were obtained by normalizing each congener to the total weight of all 2,3,7,8-substituted PCDD/F congeners. In Group 1, the proportion of PCDFs to the total amount of PCDD/Fs was $88.8 \%$ with a high proportion of $2,3,4,7,8$ PeCDF (28.4\%), 1,2,3,4,7,8-HxCDF (20.6\%), 1,2,3,6,7,8$\operatorname{HxCDF}(14.1 \%)$ and 2,3,4,6,7,8-HxCDF (10.3\%). In Group 2, $2,3,4,7,8$-PeCDF was the most abundant congener (35.3\%) with higher fraction of $2,3,4,6,7,8-\mathrm{HxCDF}(10.2 \%)$, and the total contribution of 2,3,7,8-substitued PCDFs was $70.8 \%$. In Group 3, the congener 2,3,4,7,8-PeCDF contributed dominantly to the total TEQ with $31.4 \%$. Other significant contributor were as follows: $2,3,7,8$-TCDD (24.6\%), 2,3,7,8TCDF (17.5\%) and 1,2,3,7,8-PeCDD (14.4\%). PCDF isomer distributions indicated that low-chlorinated dibenzofurans were more than the high-chlorinated dibenzofurans. The ratios of PCDFs to PCDDs for all gas samples were over 1, implying the dominant role of de novo synthesis (Everaert and Baeyens, 2002; Ooi and Lu, 2011).

\section{Concentration and TEQ Distribution of PCDD/F \\ Congeners in Stack Gas from MSWIs and HWIs}

Emission concentrations of $17 \mathrm{PCDD} / \mathrm{Fs}$ congeners and TEQ values in stack gas from 5 MSWIs and 4 HWIs were presented in Figs. 5 and 6. As shown in Fig. 5, the contribution of OCDD (37.6\%) and 1,2,3,4,6,7,8-HpCDD $(14.2 \%)$ in terms of total concentration were higher than other congeners. Notably, OCDD is the dominant congener in stack gas. However, for TEQ concentration, the 2,3,4,7,8PeCDF, 2,3,4,6,7,8-HxCDF and 1,2,3,7,8-PeCDD were the dominant congeners of PCDD/Fs in stack gas, and accounted for $38.5 \%, 9.4 \%$ and $8.86 \%$, respectively. They contribute over $50 \%$ of the total TEQ. Li et al. (2017) and Zhu et al. (2018) also found that 2,3,4,7,8-PeCDF was the largest contributor in MWIs, this conclusion was supported by the previous works (Bie et al., 2007; Choi et al., 2008; Gao et al., 2009; Yoon et al., 2017; Trinh and Chang, 2018; Zhu et al., 2018).

The congener profiles in the stack gas from HWIs were shown in Fig. 6. According to these TEQ results, the congener profiles of HWIs could be classified into three main groups: (1) PCDFs were more abundant than PCDDs with 2,3,4,7,8- PeCDF (28.4\%), 1,2,3,4,7,8-HxCDF(20.6\%) and $1,2,3,6,7,8-\mathrm{HxCDF}(14.1 \%)$ as major congeners (e.g., HW01 and HW02); (2) the percentages of PCDFs and PCDDs were $59.17 \%$ and $40.83 \%$, respectively, with $2,3,4,7,8$ PeCDF (31.4\%) and 2,3,7,8-TCDD (24.61\%) as major congeners (e.g., HW03); (3) PCDFs were more abundant than PCDDs with high proportions of 2,3,4,7,8-PeCDF $(37.34 \%)$ congener (e.g., HW04). We concluded that the de novo synthesis was always dominant.

\section{Influence of PCDD/F Emissions on the Surrounding Atmosphere}

The concentrations and the PCDD/Fs patterns in the ambient 


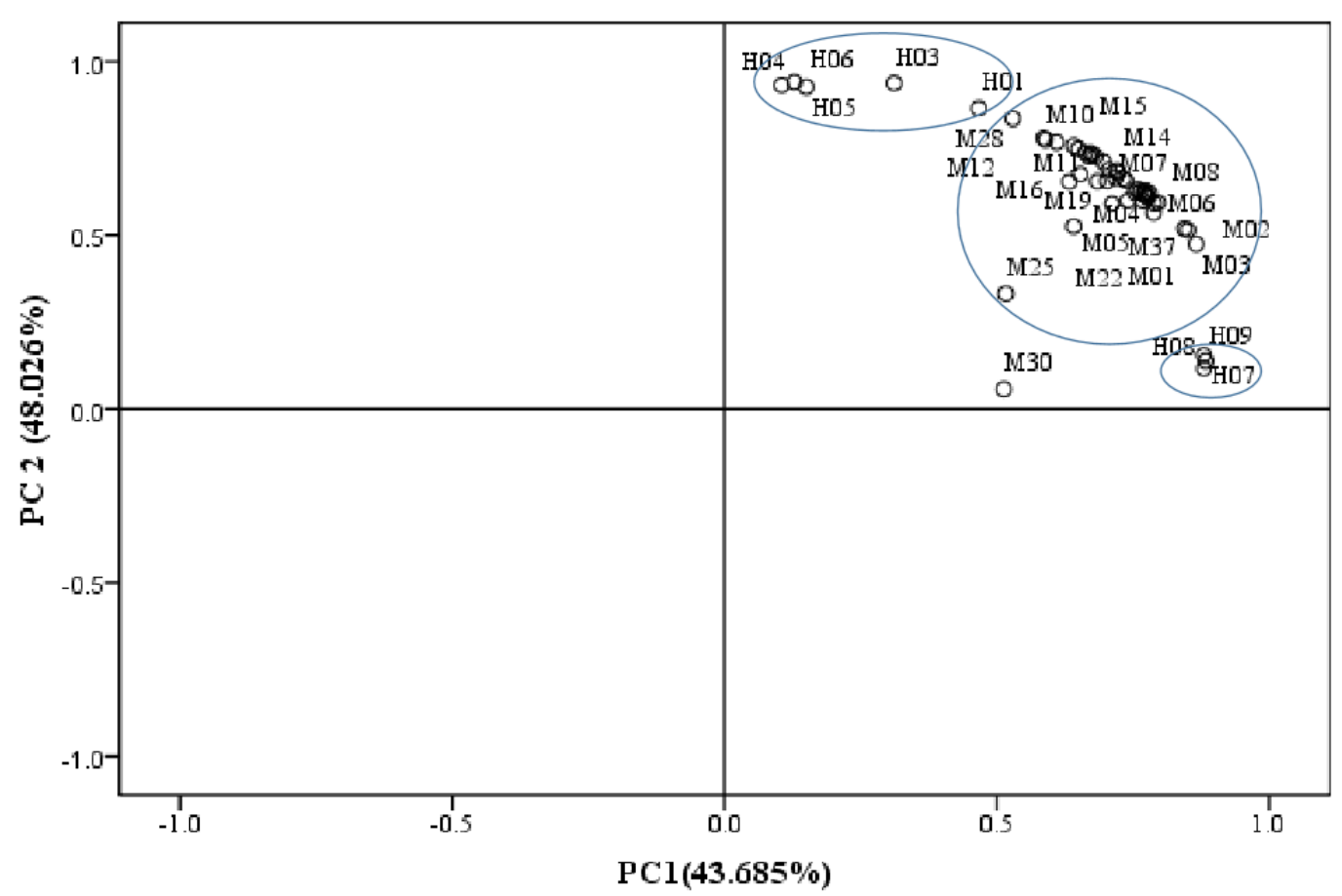

Fig. 3. Score plot of principal component analysis of 17 toxic PCDD/F emission.

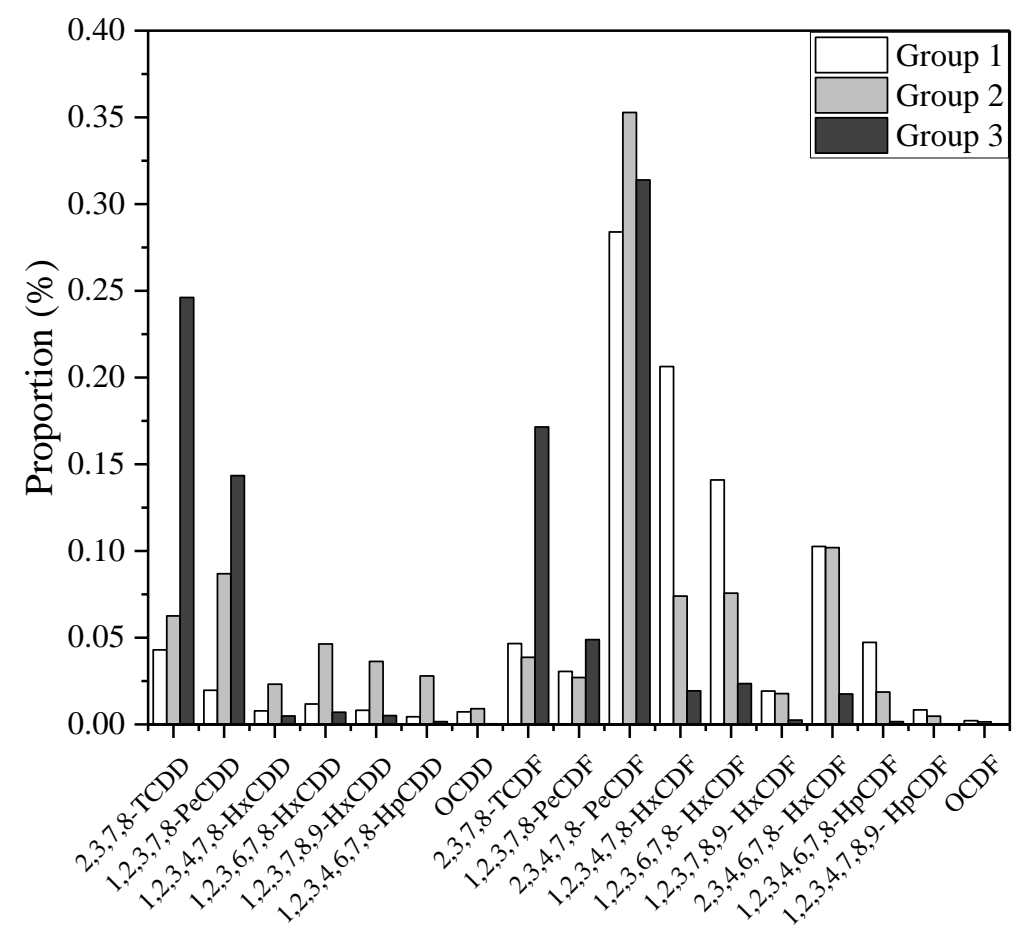

Fig. 4. Representative congener patterns of PCDD/Fs in each group (Group 1: H01-H06, Group 2: M01-M39 and H10H12, Group 3: H07-H09).

air were studied to determine if the PCDD/F emissions from each plant affecting their surrounding environment.

As could be seen from Table 2, the PCDD/F concentrations in the ambient air varied between 0.088 and $13.9 \mathrm{pg} \mathrm{I-TEQ}^{-3}$

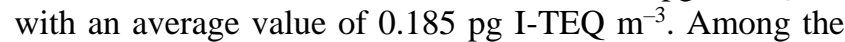
monitoring sites, MW01-A3 showed the highest PCDD/F concentration, which was roughly two order of magnitude higher than those in other sites. The possible factor was due to the location that was by the chimney. These values except MW01-A3 which was by the chimney were all below the emission limit of national standard in Japan $\left(0.6 \mathrm{pg} \mathrm{I}^{-T E Q ~ ~^{-3}}\right)$. $\mathrm{Xu}$ et al. (2009) founded that the PCDD/F concentrations in

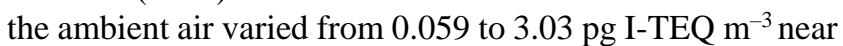
the MSWIs in eastern China. Oh et al. (2006) reported that 


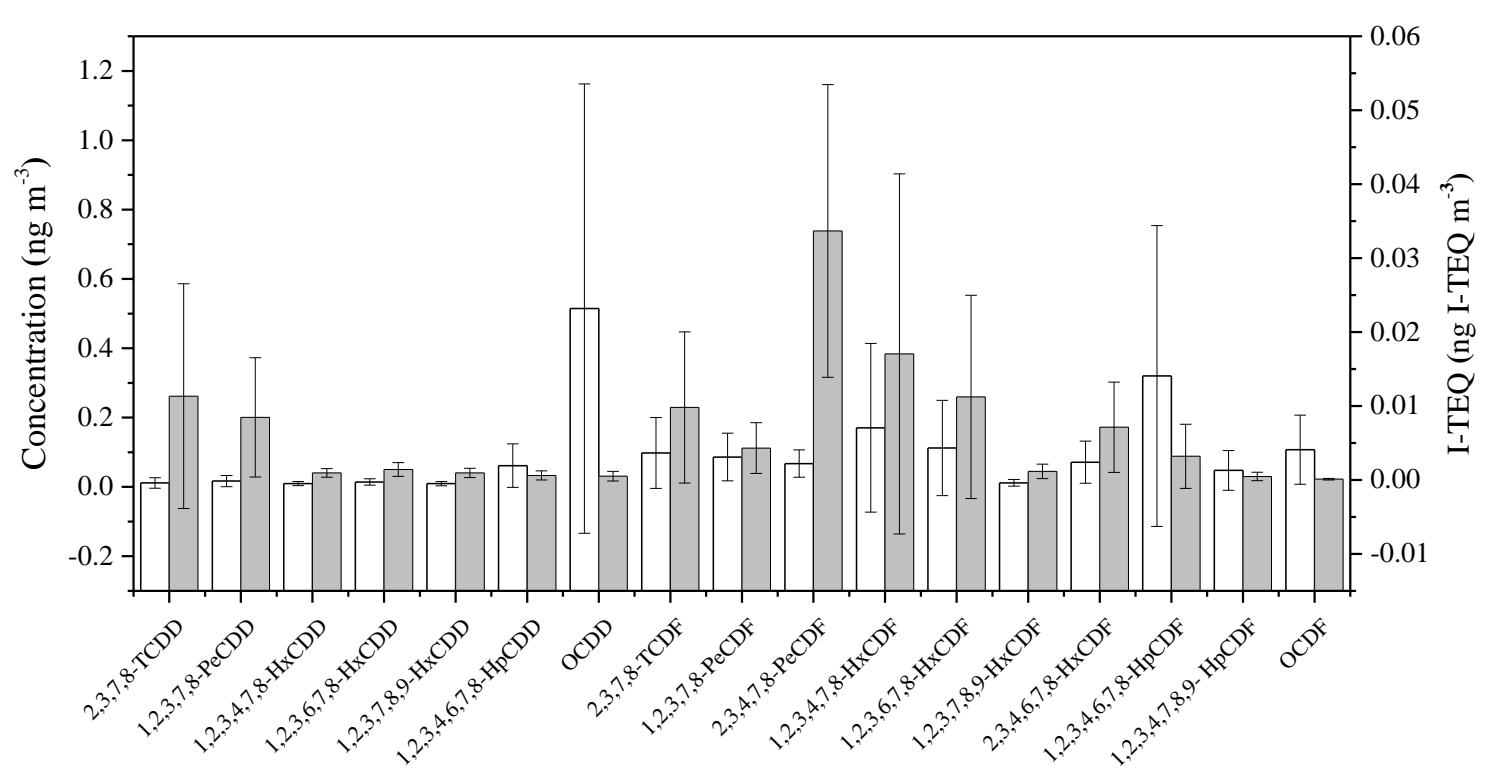

Fig. 5. PCDD/F congeners distribution and TEQ in stack gas from MSWIs.

the levels of PCDD/Fs in ambient air near a MSWI in Korea were $0.22-1.16 \mathrm{pg}$ I-TEQ $\mathrm{m}^{-3}$ with an average of 0.66 pg I-TEQ $\mathrm{m}^{-3}$. Li et al. (2018) reported that the concentration of PCDD/Fs in surrounding atmosphere of MSWIs in China

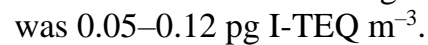

It could be seen that PCDD/F concentrations was high in winter and low in summer in the same sites. The possible factors were the difference of waste composition, temperature conditions. It could be seen that PCDD/F concentrations of the samples collected by the chimney were higher than the concentrations of the samples collected in the boundary of the plants. we could observe a trend of declining PCDD/Fs levels as the distance increased. If PCDD/Fs levels tended to decrease as the distance from a certain site increase, then the site could be considered a source of PCDD/Fs (Oh et al., 2006). Comparing the sample MW01-A3 and HW03-A2, we can see that when the PCDD/F concentrations in the stack gas emitted from the plant were relatively low, the corresponding levels in the ambient air were also lower (Hu et al., 2014).

As could be seen in Fig. 7, the concentration of 2,3,4,7,8$\mathrm{PeCDF}$ in the ambient air was higher than other congener of PCDD/Fs, and the PCDD/Fs congener profiles of them were similar with each other, the result was similar with the previous study by Chen et al. (2015) and Oh et al. (2006).

Fig. 8 shows comparison of PCDD/Fs patterns in ambient air and stack gas, the relative importance of the individual congener was normalized to the total I-TEQ value. Among all PCDD/F congeners, 2,3,4,7,8-PeCDF was the most predominant $\left(21.1 \%-40.5 \%\right.$ to the $\left.\sum \mathrm{PCDD} / \mathrm{Fs}\right)$, and the content of PCDFs was higher than PCDDs, Ratios of PCDF/PCDD varied from 0.688 to 0.831 , and the less chlorinated PCDD/Fs were the main congeners in the ambient air, these were also true with peer investigation (Oh et al., 2006; Xu et al., 2009; Hu et al., 2014; Chen et al., 2015). Besides, PCDD/Fs patterns in ambient air were similar to the patterns in the stack gas samples. These results indicated that PCDD/F emission from the plants had an obvious impact on the environments surrounding the plants.

\section{Congener Profiles and Levels of PCDD/Fs in Surrounding Soil}

Table 4 summarized the content of PCDD/Fs in soils. The I-TEQ values of PCDD/F ranged from 0.68 to $3.76 \mathrm{ng}$ ITEQ $\mathrm{kg}^{-1}$ in soils in the vicinity of MSWIs, with an average and a median value of 1.73 and $1.51 \mathrm{ng}$ I-TEQ $\mathrm{kg}^{-1}$. The I-TEQ values of PCDD/F ranged from 0.91 to $16.0 \mathrm{ng}$ I-TEQ $\mathrm{kg}^{-1}$ in soils in the vicinity of HWIs, with an average and a median value of 7.93 and $7.41 \mathrm{ng}$ I-TEQ $\mathrm{kg}^{-1}$. The values of TEQ in the soil samples in the vicinity of MSWIs and HWIs were comparable with those in surrounding soil of MSWI in China (0.39-5.04 pg I-TEQ g ${ }^{-1}$ ) (Yan et al., 2008) and (7.62-15.5 ng I-TEQ $\mathrm{kg}^{-1}$ ) (Li et al. 2018), the iron and steel plant (0.16-4.5 ng I-TEQ kg-1) (Zhou et al., 2019), hospital waste incinerator (0.46-2.63 ng I-TEQ kg-1) (Li et al., 2012) and lower than those in the vicinity of electronic wastes disposal sites in Indian (8-99 ng I-TEQ kg ${ }^{-1}$ ) (Chakraborty et al., 2018). For the ratio of the PCDF/PCDD (F/D) ranged from $0.05-1.72$ with a mean value of 0.52 . Among 11 surrounding soil samples, there were 9 samples whose F/D ratio below 1, suggesting combustion was not the mainly source of PCDD/Fs in surrounding soil (Li et al., 2018). The 2 surrounding soil samples $(\mathrm{F} / \mathrm{D}=1.51,1.72)$ from HW03 and HW04, indicating abundant enrichment of PCDFs in these soil sample, and the high TEQ of PCDD/Fs was formed because of the long-term deposition of pollutants in the vicinity of HWIs (Nganai et al., 2014).

As shown in Fig. 9. For mass concentration of PCDD/Fs, among all soil samples, OCDD was the predominant congener, accounting for $28.3 \%-77.7 \%$ of the total concentration of 17 congeners for soil samples, followed by the high-chlorinated congeners 1,2,3,4,6,7,8-HpCDD, 1,2,3,4,6,7,8-HpCDF, and OCDF, which was consistent with those previously reported by other investigators (Yan et al., 2008; Meng et al., 2016; Zhou et al., 2019; Li et al., 2018). 

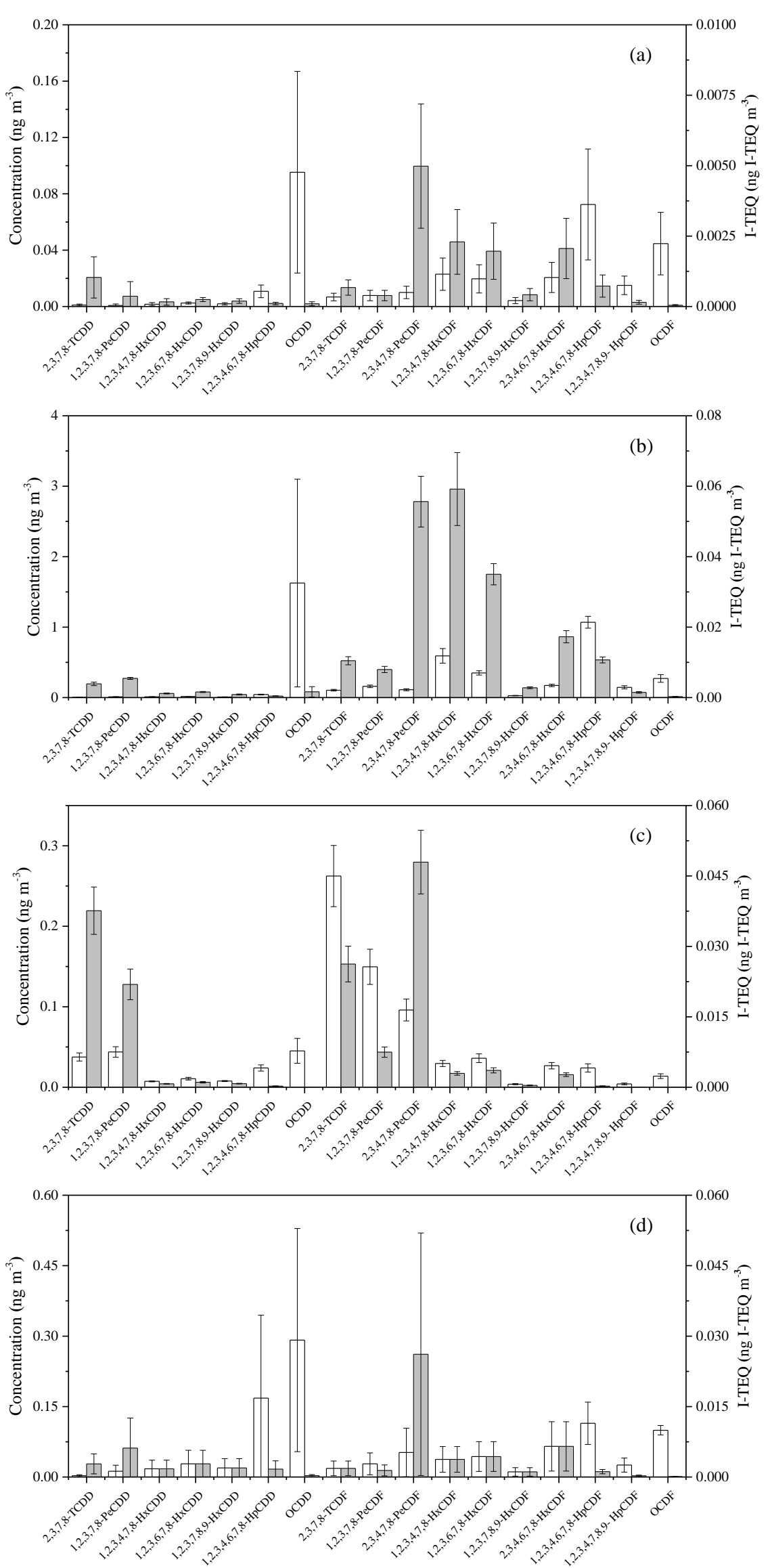

Fig. 6. PCDD/F congeners distribution and TEQ in stack gas from HWIs (a: HW01, b: HW02, c: HW03, d: HW04). 


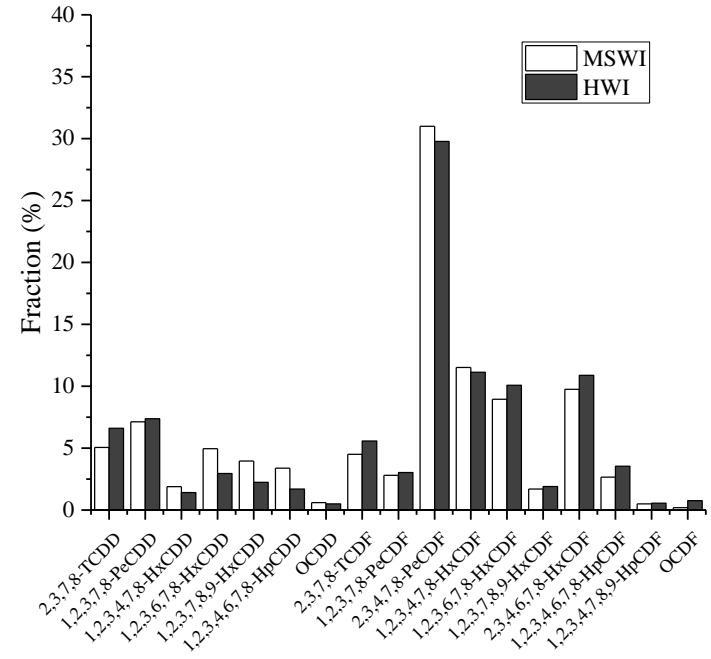

Fig. 7. $\mathrm{PCDD} / \mathrm{F}$ congener profiles in the ambient air of MSWI and HWI.

\section{CONCLUSIONS}

In this study, all of the investigated MSWIs exhibited a small variation in $\mathrm{PCDD} / \mathrm{F}$ emissions to the atmosphere (0.051-0.078 $\mathrm{ng}$ I-TEQ $\mathrm{m}^{-3}$ with an average value of 0.058 ng I-TEQ $\mathrm{m}^{-3}$ ), and the emission levels of 5 MSWIs were

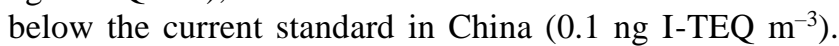
However, the emission of PCDD/Fs from the investigated HWIs ranged from $0.016-0.29 \mathrm{ng}$ I-TEQ $\mathrm{m}^{-3}$ with an average value of $0.159 \mathrm{ng}$ I-TEQ $\mathrm{m}^{-3}$. Two HWIs had emission levels above the current standard in China, indicating that incineration technologies should be further improved. The emission factors of PCDD/Fs to the atmosphere were in the range of 0.056 to $0.607 \mu \mathrm{g}$ I-TEQ $\mathrm{t}^{-1} \mathrm{MSW}$ (mean: 0.235 $\mu \mathrm{g} \mathrm{I-TEQ} \mathrm{t}^{-1}$ ) and 0.07-3.27 $\mu \mathrm{g} \mathrm{I}$-TEQ t$^{-1} \mathrm{HW}$ (mean: 1.03 $\mu \mathrm{g} \mathrm{I-TEQ} \mathrm{t}^{-1}$ ), respectively. It was estimated that $10.2-88.0 \mathrm{mg}$ (mean: $35.0 \mathrm{mg}$ ) and 1.13-53.0 mg (mean: $17.1 \mathrm{mg}$ ) I-TEQ of PCDD/Fs were annually released from MSWIs and HWIs to the atmosphere in China, respectively. Based on principal
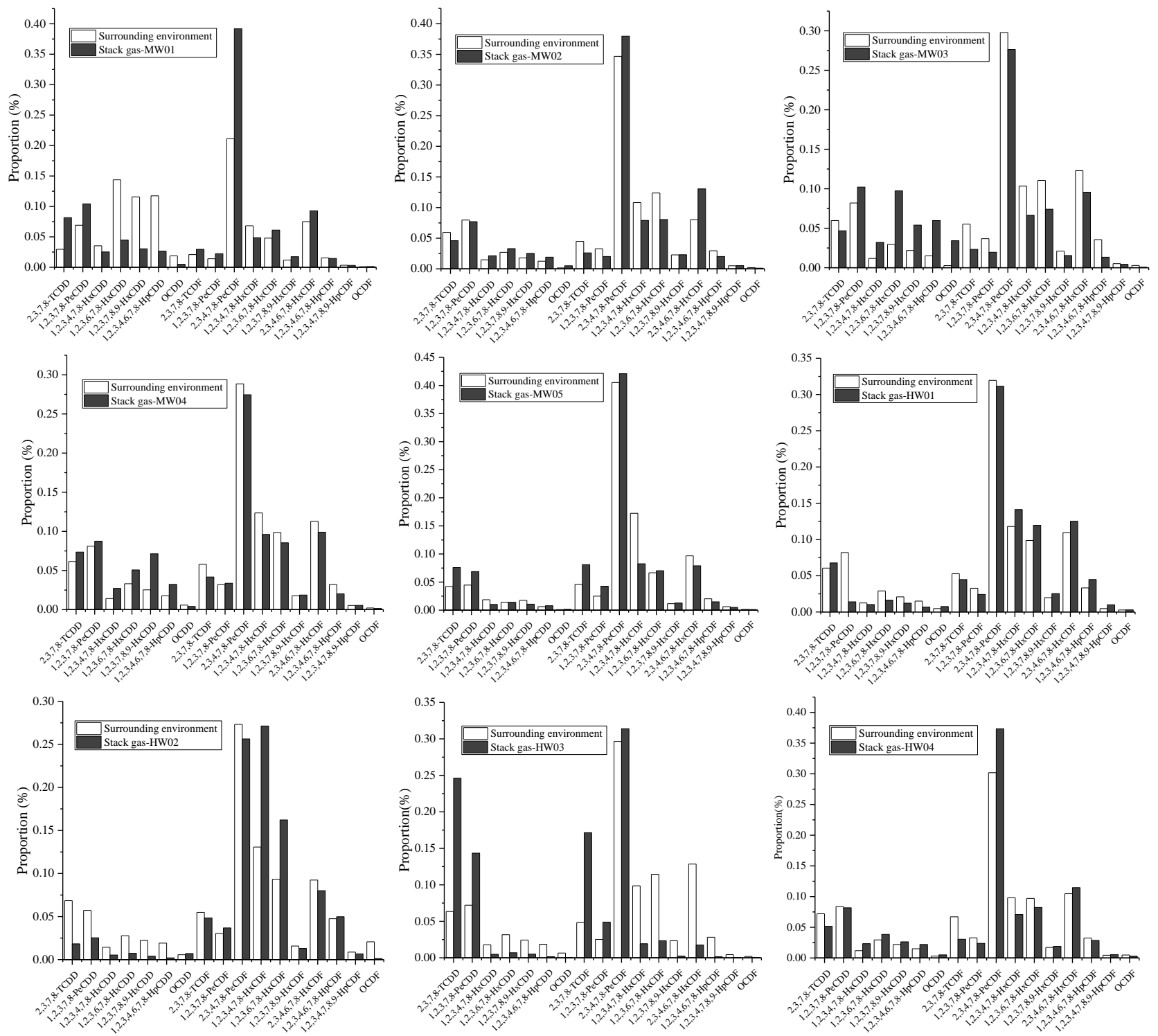

Fig. 8. Comparison of PCDD/Fs patterns in ambient air and stack gas. 


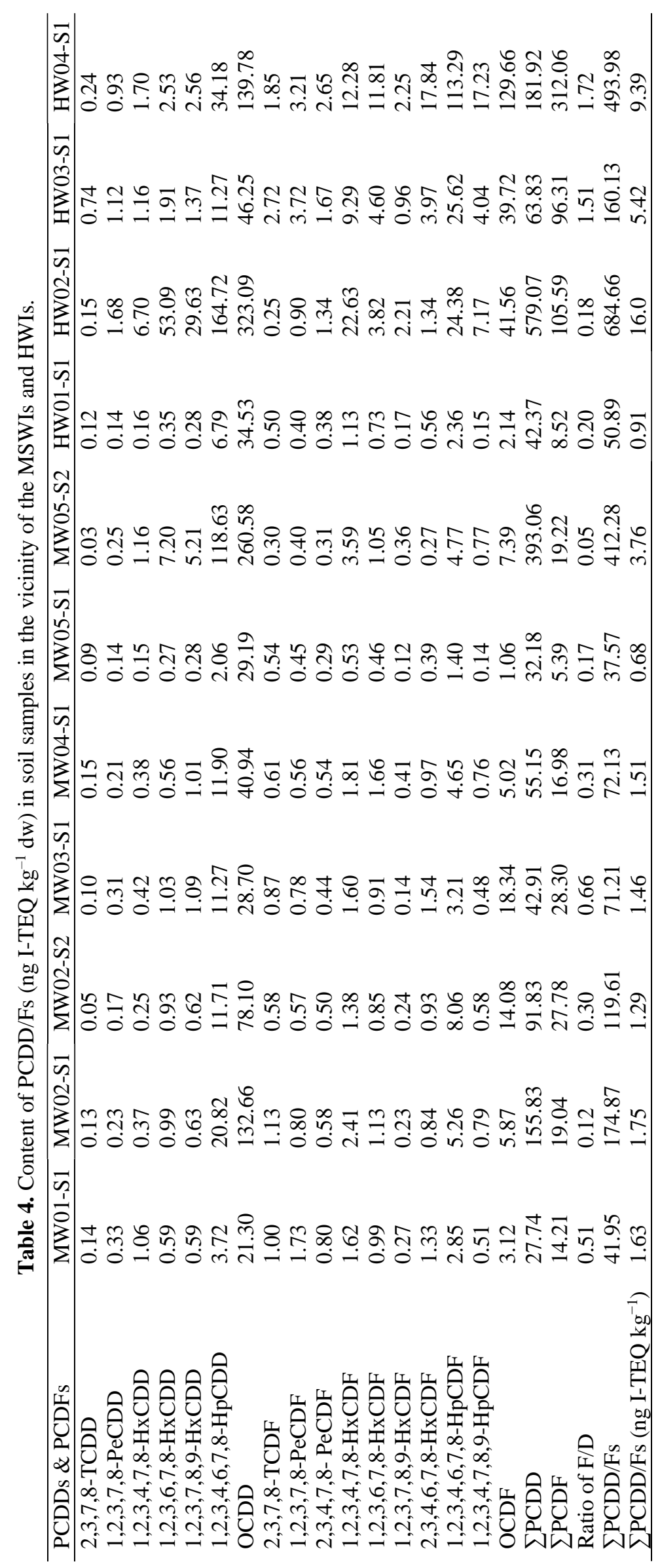




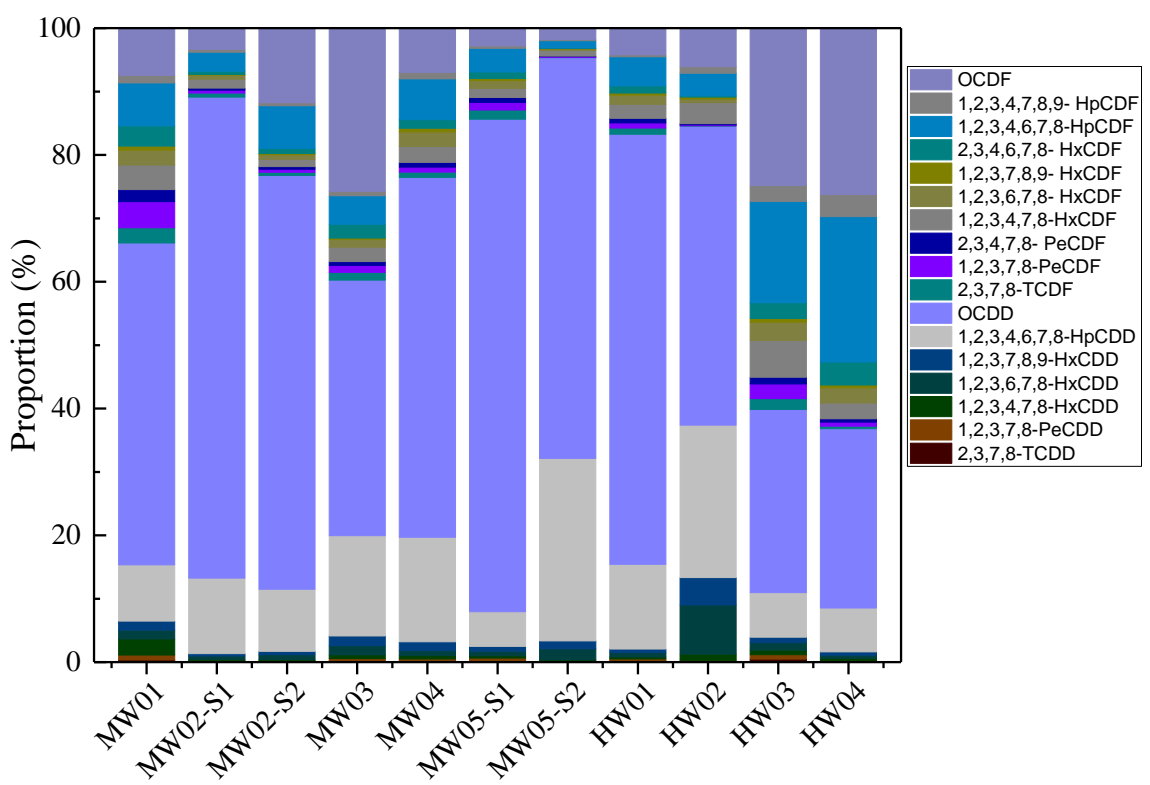

Fig. 9. Composition profiles of PCDD/Fs in the soil samples in the vicinity of MSWIs and HWIs.

component analysis, most MSWIs belonged to Group 2, and 4 investigated HWIs could be divided into three groups because of different feeding wastes. Our results indicated that PCDD/F emission from the plants had an obvious impact on the $\mathrm{PCDD} / \mathrm{F}$ concentration and patterns in ambient air. The I-TEQ values of PCDD/F in soil samples in the vicinity of MSWIs were lower than those around the HWIs.

\section{ACKNOWLEDGEMENTS}

This Project was supported by the National Key Research and Development Plan of China (No. 2018YFC1901300) and the Innovative Research Groups of the National Natural Science Foundation of China (No. 51621005) and the National Natural Science Foundation of China (No. 51976192).

\section{REFERENCE}

Bai, S.T., Chang, S.H., Duh, J.M, Sung, F.H., Su, J.S. and Chang, M.B. (2017). Characterization of PCDD/Fs and dioxin-like PCBs emitted from two woodchip boilers in Taiwan. Chemosphere 189: 284-290. https://doi.org/10.1 016/j.chemosphere.2017.09.080

Bie, R.S., Li, S.Y. and Wang, H. (2007). Characterization of $\mathrm{PCDD} / \mathrm{Fs}$ and heavy metals from MSW incineration plant in Harbin. Waste Manage. 27: 1860-1869. https://doi.org/ 10.1016/j.wasman.2006.10.014

Chakraborty, P., Selvaraj, S., Nakamura, M., Prithiviraj, B., Cincinelli, A. and Bang, J.J. (2018). PCBs and PCDD/Fs in soil from informal e-waste recycling sites and open dump sites in India: Levels, congener profiles and health risk assessment. Sci. Total Environ. 621: 930-938. https://doi.org/10.1016/j.scitotenv.2017.11.083

Chen, T., Gu, Y.L., Yan, J.H., Li, X.D., Lu, S.Y., Dai, H. and Cen, K.F. (2008). Polychlorinated dibenzo- $p$-dioxins and dibenzofurans in flue gas emissions from municipal solid waste incinerators in China. Zhejiang Univ. Sci. A9:
1296-1303. https://doi.org/10.1631/jzus.A0720144

Chen, T., Guo, Y., Li, X.D., Lu, S.Y. and Yan, J.H. (2014). Emissions behavior and distribution of polychlorinated dibenzo- $p$-dioxins and furans (PCDD/Fs) from cement kilns in China. Environ. Sci. Pollut. Res. 21: 4245-4253. https://doi.org/10.1007/s11356-013-2356-8

Chen, T., Zhan, M.X., Lin, X.Q., Fu, J.Y., Lu, S.Y. and Li, X.D. (2015). Distribution of PCDD/Fs in the fly ash and atmospheric air of two typical hazardous waste incinerators in eastern China. Environ. Sci. Pollut. Res. 22: 12071214. https://doi.org/10.1007/s11356-014-3401-y

Chen, T., Zhan, M.X., Lin, X.Q., Li, Y.Q., Zhang, J., Li, X.D., Yan, J.H. and Buekens, A. (2016). Emission and distribution of $\mathrm{PCDD} / \mathrm{Fs}$ and $\mathrm{CBzs}$ from two coprocessing RDF cement plants in China. Environ. Sci. Pollut. Res. 23: 11845-11854. https://doi.org/10.1007/s1 1356-016-6403-0

China MEP (2014). Environmental Sanitation Standard for Incineration of Medical Treatment Waste. The Ministry of Environmental Protection of China. GB18485-2014. (in Chinese).

Choi, K.I., Lee, S.H. and Lee, D.H. (2008). Emissions of PCDDs/DFs and dioxin-like PCBs from small waste incinerators in Korea. Atmos. Environ. 42: 940-948. https://doi.org/10.1016/j.atmosenv.2007.10.011

Dopico, M. and Gomez, A. (2015). Review of the current state and main sources of dioxins around the world. J. Air Waste Manage. Assoc. 65: 1033-1049. https://doi.org/10. 1080/10962247.2015.1058869

Duan, H., Huang, Q., Wang, Q., Zhou, B. and Li, J. (2008). Hazardous waste generation and management in China: A review. J. Hazard. Mater. 158: 221-227. https://doi.org/1 0.1016/j.jhazmat.2008.01.106

Everaert, K. and Baeyens, J. (2002). The formation and emission of dioxins in large scale thermal process. Chemosphere 46: 439-448. https://doi.org/10.1016/S00456535(01)00143-6 
Gao, H.C., Ni, Y.W., Zhang, H.J., Zhao, L., Zhang, N., Zhang, X.P., Zhang, Q. and Chen, J.P. (2009). Stack gas emissions of PCDD/Fs from hospital waste incinerators in China. Chemosphere 77: 634-639. https://doi.org/10.1 016/j.chemosphere.2009.08.017

Hu, J.C., Zheng, M.H., Liu, W.B., Nie, Z.Q., Li, C.L., Liu, G.R. and Xiao, K. (2014). Characterization of polychlorinated dibenzo- $p$-dioxins and dibenzofurans, dioxin-like polychlorinated biphenyls, and polychlorinated naphthalenes in the environment surrounding secondary copper and aluminum metallurgical facilities in China. Environ. Pollut. 193: 6-12. https://doi.org/10.1016/j.env pol.2014.06.007

Huang, H. and Buekens, A. (1995). On the mechanisms of dioxin formation in combustion processes. Chemosphere 31: 4099-4117. https://doi.org/10.1016/0045-6535(95)80 011-9

Li, J.F., Lv, Z.W., Du, L., Li, X.N., Hu, X.P., Wang, C., Niu, Z.G. and Zhang, Y. (2017). Emission characteristic of polychlorinated dibenzo- $p$-dioxins and polychlorinated dibenzofurans (PCDD/Fs) from medical waste incinerators (MWIs) in China in 2016: A comparison between higher emission levels of MWIs and lower emission levels of MWIs. Environ. Pollut. 221: 437-444. https://doi.org/10.1016/j.envpol.2016.12.009

Li, J.F., Zhang, Y., Sun, T.T., Hao, H.W., Wu, H., Wang, L.L., Chen, Y.X., Xing, L.M. and Niu, Z.G. (2018). The health risk levels of different age groups of residents living in the vicinity of municipal solid waste incinerator posed by PCDD/Fs in atmosphere and soil. Sci. Total Environ. 631-632: 81-91. https://doi.org/10.1016/j.scitot env.2018.03.009

Li, X.D., Yan, M., Yang, J., Chen, T., Lu, S.Y. and Yan, J.H. (2012). PCDD/Fs in soil around a hospital waste incinerator: Comparison after three years of operation. $J$. Environ. Sci. 24: 699-703. https://doi.org/10.1016/S10010742(11)60752-3

Lu, J.W., Zhang, S.K., Hai, J. and Lei, M. (2017). Status and perspectives of municipal solid waste incineration in China: A comparison with developed regions. Waste Manage. 69: 170-186. https://doi.org/10.1016/j.wasman.2017.04.014

Luijk, R., Akkerman, D.M., Slot, P., Olie, K. and Kapteijn, F. (1994). Mechanism of formation of polychlorinated dibenzo- $p$-dioxins and dibenzofurans in the catalyzed combustion of carbon. Environ. Sci. Technol. 28: 312 321. https://doi.org/10.1021/es00051a019

Meng, B., Ma, W.L., Liu L.Y., Zhu, N.Z., Song, W.W., Lo, C.Y., Li, J., Kannan, K. and Li, Y.F. (2016). PCDD/Fs in soil and air and their possible sources in the vicinity of municipal solid waste incinerators in northeastern China. Atmos. Pollut. Res. 7: 355-362. https://doi.org/10.1016/j. apr.2015.10.014

Nganai, S., Dellinger, B. and Lomnicki, S. (2014). PCDD/PCDF Ratio in the Precursor Formation Model over CuO Surface. Environ. Sci. Technol. 48: 1386413870. https://doi.org/10.1021/es504253w

Ngo, T.H., Tsou, H.H., Chen, Y.F., Chen, Y.W. and Chi, K.H. (2018). Sources identification of PCDD/Fs in soil and atmospheric deposition in Taiwan. Chemosphere
208: 374-381. https://doi.org/10.1016/j.chemosphere.2018. 05.195

Ni, Y.W, Zhang, H.J., Fan, S., Zhang, X.P., Zhang, Q. and Chen, J.P. (2009). Emissions of PCDD/Fs from municipal solid waste incinerators in China. Chemosphere 75: 11531158. https://doi.org/10.1016/j.chemosphere.2009.02.051

Nzihou, A., Themelis, N.J., Kemiha, M. and Benhamou, Y. (2012). Dioxin emissions from municipal solid waste incinerators (MSWIs) in France. Waste Manage. 32: 2273-2277. https://doi.org/10.1016/j.wasman.2012.06.016

Oh, J.E., Choi, S.D., Lee, S.J. and Chang, Y.S. (2006). Influence of a municipal solid waste incinerator on ambient air and soil PCDD/Fs levels. Chemosphere 64: 579-587. https://doi.org/10.1016/j.chemosphere.2005.11.012

Ooi, T.C. and Lu, L.M. (2011). Formation and mitigation of $\mathrm{PCDD} / \mathrm{Fs}$ in iron ore sintering. Chemosphere 85: 291299. https://doi.org/10.1016/j.chemosphere.2011.08.020

Pham, M.T.N., Anh, H.Q., Nghiem, X.T., Tu, B.M., Dao, T.N. and Nguyen, M.H. (2019a). Characterization of PCDD/Fs and dioxin-like PCBs in flue gas from thermal industrial processes in Vietnam: A comprehensive investigation on emission profiles and levels. Chemosphere 225: 238-246. https://doi.org/10.1016/j.chemosphere.2019.03.024

Pham, M.T.N., Hoang, A.Q., Nghiem, X.T., Tu, B.M., Dao, T.N. and $\mathrm{Vu}, \mathrm{D} . \mathrm{N}$. (2019b). Residue concentrations and profiles of PCDD/Fs in ash samples from multiple thermal industrial processes in Vietnam: Formation, emission levels, and risk assessment. Environ. Sci. Pollut. Res. 26: 17719-17730. https://doi.org/10.1007/s11356019-05015-2

National Bureau of Statistics of China (2008, 2018). China Statistical Yearbook. China Statistical Publishing House, Beijing (in Chinese).

Trinh, M.M. and Chang, M.B. (2018). Review on occurrence and behavior of PCDD/Fs and dl-PCBs in atmosphere of East Asia. Atmos. Environ. 180: 23-36. https://doi.org/10.1016/j.atmosenv.2018.02.037

Tuppurainen, K.A., Ruokojärvi, P.H., Asikainen, A.H., Aatamilla, M. and Ruusanaen, J. (2000). Chlorophenols as precoursors of $\mathrm{PCDD} / \mathrm{Fs}$ in incineration process: correlation, PLS modeling, and reaction mechanisms. Environ. Sci. Technol. 34: 4958-4962. https://doi.org/10. 1021/es991429x

U.S. EPA (1995). Method 23. Determination of polychlorinated dibenzo- $p$-dioxins and polychlorinated dibenzofurans froms municipal waste combustors. U.S. EPA, Washington.

U.S. EPA (1999). TO-9A. Compendium Method TO-9Adetermination of polychlorinated, polybrominated and brominated/chlorinated dibenzo- $p$-dioxins and dibenzofurans in ambient air, in Compendium of Methods for the Determination of Toxic Organic Compounds in Ambient Air, 2nd ed. Office of Research and Development, EPA/625/R-96/010b, January 1999, in Air Toxic Methods.

Wang, L.C., Lee, W.J., Lee, W.S., Chang-Chien, G.P. and Tsai, P.J. (2003). Effect of chlorine content in feeding wastes of incineration on the emission of polychlorinated dibenzo-p-dioxins/dibenzofurans. Sci. Total Environ. 302: 185-198. https://doi.org/10.1016/S0048-9697(02)00306-6 
Wang, M., Liu, G.R., Jiang, X.X., Xiao, K. and Zheng, M.H. (2015). Formation and potential mechanisms of polychlorinated dibenzo- $p$-dioxins and dibenzofurans on fly ash from a secondary copper smelting process. Environ. Sci. Pollut. Res. 22: 8747-8755. https://doi.org/10.1007/s11356-014-4046-6

Wikstrom, E., Lofvenius, G., Rappe, C. and Marklund, S. (1996). Influence of level and form of chlorine on the formation of chlorinated dioxins, dibenzofurans, and benzenes during combustion of an artificial fuel in a laboratory reactor. Environ. Sci. Technol. 30: 1637-1644. https://doi.org/10.1021/es9506364

Xu, M.X., Yan, J.H., Lu, S.Y., Li, X.D., Chen, T., Ni, M.J., Dai, H.F., Wang, F. and Cen, K.F. (2009). Concentrations, profiles, and sources of atmospheric $\mathrm{PCDD} / \mathrm{Fs}$ near a municipal solid waste incinerator in eastern China. Environ. Sci. Technol. 43: 1023-1029. https://doi.org/10.1021/es802183b

Yan, J.H., Xu, M.X., Lu, S.Y., Li, X.D., Chen, T., Ni, M.J., Dai, H.F. and Cen, K.F. (2008). PCDD/F concentrations of agricultural soil in the vicinity of fluidized bed incinerators of co-firing MSW with coal in Hangzhou, China. J. Hazard. Mater. 151: 522-530. https://doi.org/10. 1016/j.jhazmat.2007.06.018
Yoon, Y.W., Jeon, T.W., Son, J.I., Kim, K.Y., Kwon, E.H., Shin, S.K. and Kang, J.G. (2017). Characteristics of PCDDs/PCDFs in stack gas from medical waste incinerators. Chemosphere 188: 478-485. https://doi.org/ 10.1016/j.chemosphere.2017.09.010

Zhan, M.X., Ma, Y.F., Lin, X.Q., Chen, Z.L., Chen, T., Li, X.D. and Yan, J.H. (2019). PCDD/F emission from pharmaceutical industries. Aerosol Air Qual. Res. 19: 2070-2082. https://doi.org/10.4209/aaqr.2019.06.0284

Zhou, T., Bo, X., Qu, J.B., Wang, L.F., Zhou, J. and Li, S.B. (2019). Characteristics of PCDD/Fs and metals in surface soil around an iron and steel plant in North China Plain. Chemosphere 216: 413-418. https://doi.org/10.1016/j.ch emosphere.2018.10.024

Zhu, F., Li, X.F., Lu, J.W., Hai, J., Zhang, J.R., Xie, B. and Hong, C.Y. (2018). Emission characteristics of PCDD/Fs in stack gas from municipal solid waste incineration plants in Northern China. Chemosphere 200: 23-29. https://doi.org/10.1016/j.chemosphere.2018.02.092

Received for review, December 27, 2019

Revised, March 25, 2020

Accepted, March 29, 2020 